\title{
ACTIONS OF ANTIFERTILITY CHEMICALS ON XENOPUS LAEVIS SPERMATOZOA IN VITRO
}

\author{
PAMELA JONES AND H. JACKSON \\ Unit of Reproductive Pharmacology, University of Manchester, \\ Manchester M13 9PT
}

(Received 2nd Fuly 1973)

\begin{abstract}
Summary. A test system involving fertilization in vitro of Xenopus laevis gametes was developed to study the effects of various chemosterilants on toad spermatozoa. The subsequent development of fertilized eggs indicated that effective concentrations and times of exposure were considerably greater than those likely to be achieved with antifertility doses to rodents. Low concentrations of tretamine and ethyleneurea on Xenopus spermatozoa produced high yields of abnormal embryos, whereas other epididymal sterilants active in the rat (trimethylphosphate and $\alpha$-chlorhydrin) were ineffective in very high concentration. Differences between results in vitro and in vivo may be due to environmental variations or indicate an action by certain compounds on epididymal function in rodents rather than a direct action upon spermatozoa.
\end{abstract}

\section{INTRODUGTION}

It has been repeatedly demonstrated that a number of structurally unrelated simple chemicals exert effects upon spermatogenesis in rodents with the production of well-defined episodes of sterility (Jackson, 1964, 1970). Although these effects can be related to actions upon particular spermatogenic cell types, in that a compound can either inhibit spermatogenesis or produce a 'functional' sterilant effect upon post-meiotic cells and epididymal spermatozoa, the biochemical-pharmacological mechanisms involved remain obscure. It is with compounds of the latter type, i.e. those affecting post-meiotic cells and testicular and epididymal spermatozoa, that the present study has been concerned. For this purpose, a test system involving fertilization of Xenopus laevis gametes in vitro was developed and the effects on toad spermatozoa of various compounds producing functional sterility in rodents were followed in the subsequent development of eggs fertilized by such treated spermatozoa. Some comparison between dose levels effective in vivo and in vitro could be made.

\section{MATERIALS AND METHODS}

Details of the maintenance of adult Xenopus laevis have been frequently described (Leadley Brown, 1970; Ruddock \& Ruffle, 1972). For the present study, a colony of imported toads was housed in polypropylene boxes measuring 
$17 \frac{1}{2} \times 11 \times 5$ in., each containing three or four animals in $1 \frac{1}{4}$ to $1 \frac{1}{2}$ gallons tap water at 22 to $24^{\circ} \mathrm{C}$. The toads were cleaned out twice weekly, $24 \mathrm{hr}$ after feeding with chopped liver.

Holtfreter's solution was used for handling gametes and as a solvent for the chemicals being tested. Male and female toads were given a priming injection into the dorsal lymph sac of HCG ('Pregnyl', Organon), 50 i.u. and 100 i.u. respectively, followed 3 or 4 days later by a second dose (100 i.u. for males, 350 i.u. for the females) about 12 to $14 \mathrm{hr}$ before the gametes were required. Four or five females were normally injected to ensure the production of a sufficient number of good eggs and one female was selected for use throughout an experiment. Two male toads were killed by stunning and pithing immediately before commencing the experiment. The testes were removed and macerated at $22^{\circ} \mathrm{C}$ in Holtfreter's solution $(2 \mathrm{ml})$ to provide a sperm suspension. At the end of the experiment, a small volume of this was diluted 100-fold with the same fluid containing formalin (final concentration $0.1 \%$ ). A sperm count was made using a Neubauer counting chamber.

The sperm suspension $(0.3 \mathrm{ml})$ was thoroughly mixed with a solution $(1.2 \mathrm{ml})$ of the test substance over a range of concentrations; a control was also included. Haemocytometer counts indicated that the average number of spermatozoa present in suspensions $(2 \mathrm{ml})$ from four testes was about $90 \times 10^{6}$ cells $/ \mathrm{ml}$ and about $1.8 \times 10^{6}$ cells $/ \mathrm{ml}$ were used to fertilize each batch of forty to fifty eggs. The fertilization process was conducted in small Petri dishes into which eggs were freshly stripped before each fertilization. At intervals of $\frac{1}{2}, 1$ and $2 \mathrm{hr}$ of exposure of spermatozoa to the chemical, samples $(0.5 \mathrm{ml})$ were transferred to corresponding batches of eggs in Holtfreter's solution ( $4.5 \mathrm{ml}$ ), mixing being ensured by gentle agitation. About $15 \mathrm{~min}$ later, the eggs were washed into crystallizing dishes (diameter $5 \frac{3}{4}$ in.), after which the proportion fertilized could be observed by the rotation of the eggs so that the pigmented animal pole was uppermost. Development was then followed through the stages of early cleavage (Pl. 1, Fig. 1), gastrula (Pl. 1, Fig. 2), neurula (Pl. 2, Fig. 5) and tadpole (Pl. 2, Fig. 6) and the numbers of eggs developing were scored for each stage. The developmental stages of $X$. laevis have been described in detail by Nieuwkoop \& Faber (1956), and tabulated in an abbreviated form by New (1966). In the present work, eggs were scored at the early cleavage stage as normal, abnormal or uncleaved, while embryos at the gastrula, neurula and tadpole stages were assessed as normal or abnormal. Abnormalities were classified according to those illustrated for Rana pipiens (Rugh, 1962).

The compounds used in this study were methyl methanesulphonate (MMS),

\section{EXPLANATION OF PLATE 1}

All Figs $\times 30$.

FIgs 1 and 2. Normal Xenopus laevis eggs at the four-cell stage and gastrula stage, respectively.

FIG. 3. Typical abnormal early cleavages as seen after pretreatment of spermatozoa with MMS, EU or TEM.

FIG. 4. Exogastrulae encountered after pretreatment of spermatozoa with EU or TEM, where animal pole cells remain on top of the yolk. 
P... I

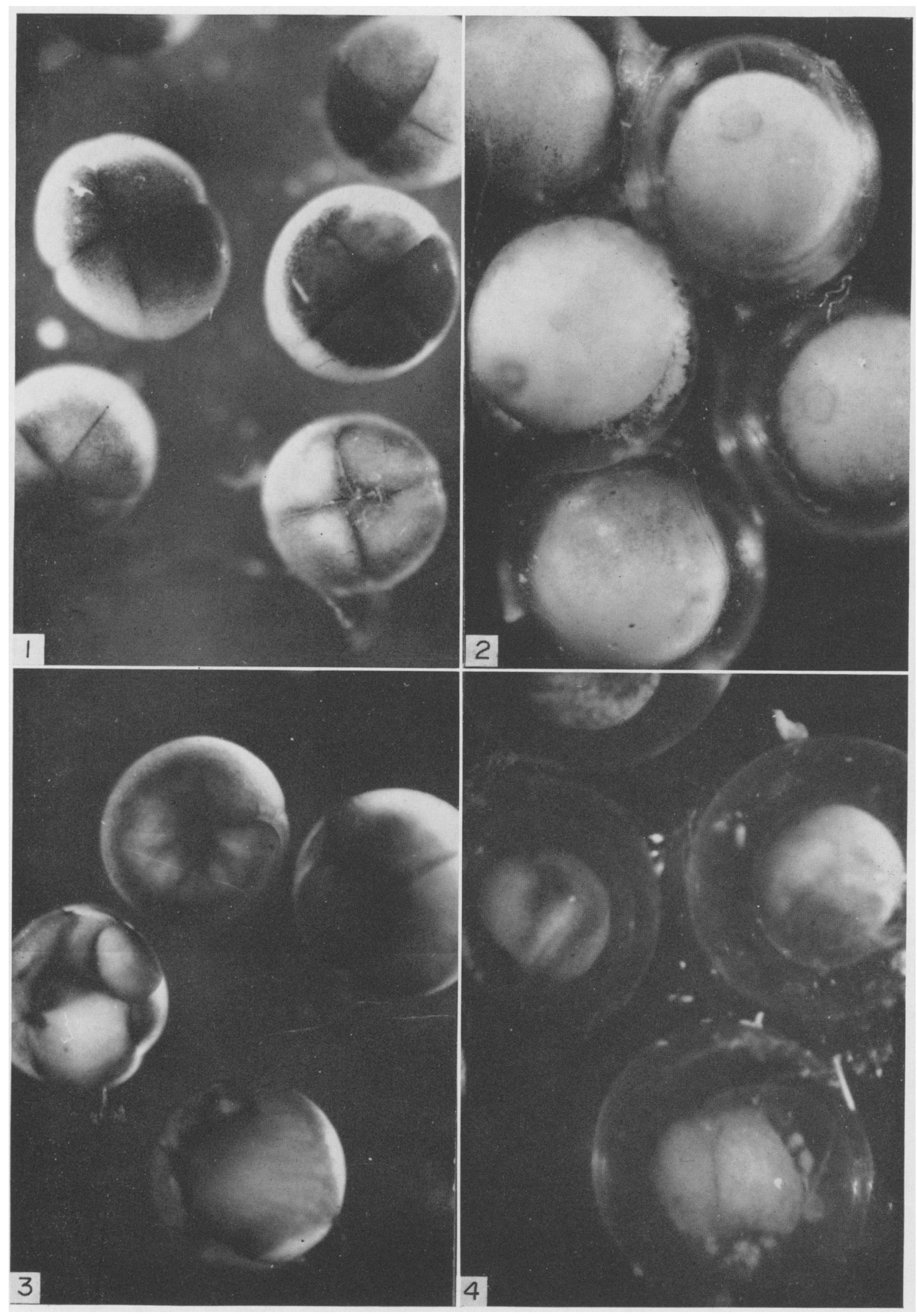


PI. III: -

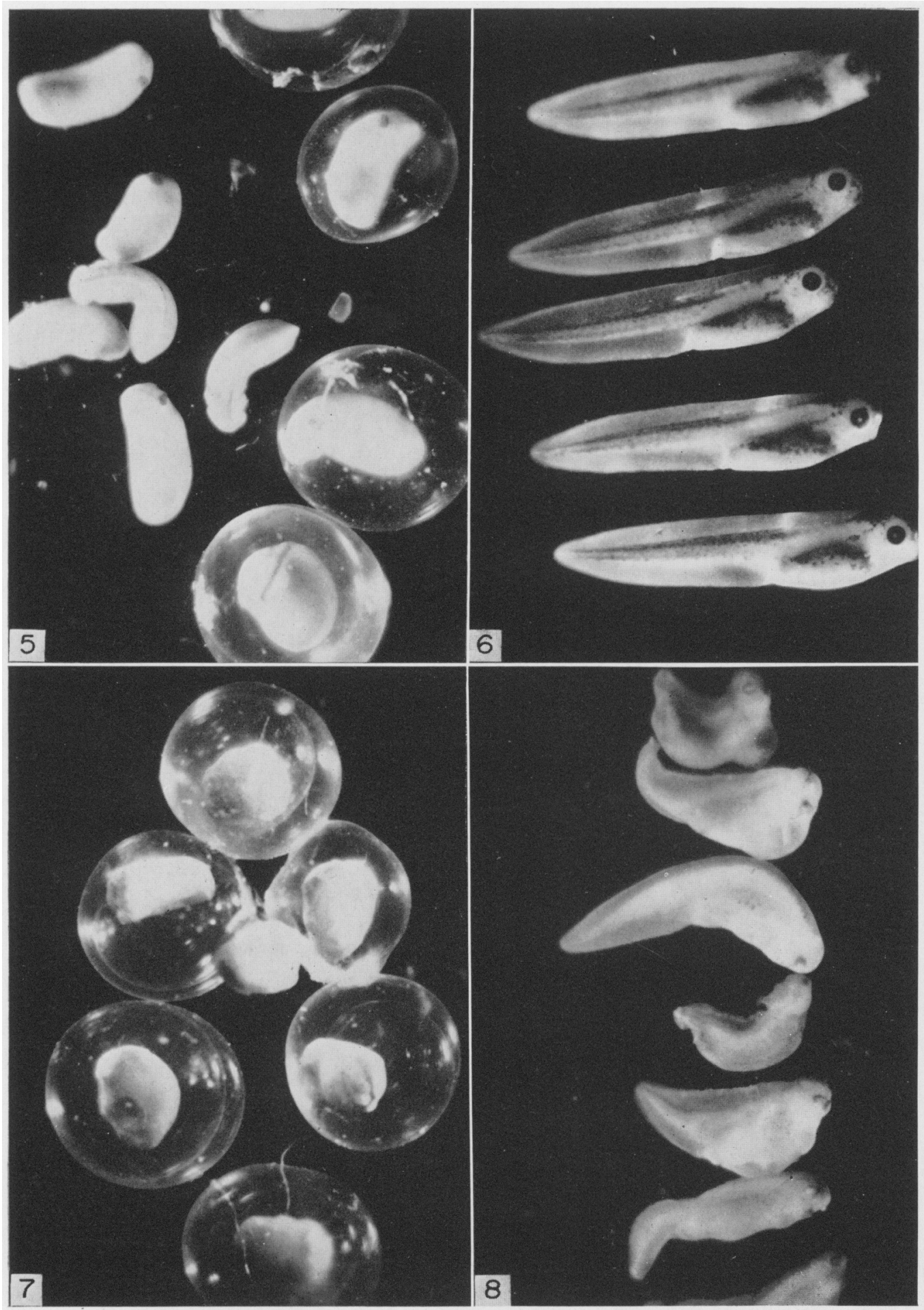


ethyleneurea (EU), tretamine (TEM), 3-chloropropane 1,2-diol ( $\alpha$-chlorhydrin), glycidol and trimethylphosphate (TMP).

\section{RESULTS}

Survival of Xenopus gametes in vitro

Eggs kept at room temperature showed a rapid decline in fertilizability with time (e.g. by $50 \%, 40 \mathrm{~min}$ after stripping from the female) but spermatozoa retained their fertilizing capacity over a longer period ( 80 to $90 \%$ over $2 \mathrm{hr}$; $50 \%$ at $4 \mathrm{hr}$ ). Experimental work with spermatozoa was therefore restricted to a period of $2 \mathrm{hr}$ after preparation of the initial suspension. The maximum dilution compatible with a high percentage of fertilization and embryonic development was 20 times the original suspension. Dilutions of 40 - to 80 -fold yielded a fertilization rate of about $40 \%$ while at 160 -fold, few eggs were fertilized. The dilution of sperm suspensions used (15-fold) was well within the limits suggested by the above results.

Abnormal cleavages were manifest as an unequal division of the egg, usually at the two-, four- or eight-cell stage, or by furrowing of the animal pole surface pigment, without concurrent division of the vegetal pole (PI. 1, Fig. 3). Abnormal gastrulae were mainly of the exogastrula type, in which the animal pole cells remained on top of the yolk (Pl. 1, Fig. 4); various other structural changes were apparent at the neurula and tadpole stages (Pl. 2, Figs 7 and 8).

\section{Exposure of Xenopus spermatozoa to antifertility chemicals}

For all compounds tested, cleavage times were normal.

Methyl methanesulphonate. A preliminary determination of the $\mathrm{pH}$ change of MMS in $\mathrm{m} / 75$ phosphate buffer $(\mathrm{pH} 7 \cdot 3)$ over a 2 -hr period showed only a small decrease (to 7.05) at the highest concentration used $(5 \mathrm{mg} / \mathrm{ml})$. Fertilization of normal eggs with treated spermatozoa $(5.0 \mathrm{mg} \mathrm{MMS} / \mathrm{ml}$ ) for 30,60 and $120 \mathrm{~min}$, resulted in a decrease in percentage of cleaving ova from $50 \%$ (30 $\mathrm{min})$ to $2 \%(120 \mathrm{~min})$ and an increase in the number of abnormal cleavages at these times (Table 1). None of the ova reached gastrulation. The remaining concentrations showed graded effects upon development, and only the lowest level $(0.1 \mathrm{mg} / \mathrm{ml})$ was without effect upon the fertilizing capacity or subsequent egg development. Sperm motility was not distinctly reduced except after a 2-hr exposure to the highest concentration of MMS.

Ethyleneurea. Over the concentration range of 2.0 to $0.125 \mathrm{mg} \mathrm{EU} / \mathrm{ml}$, cleavage rates were high at all levels after 30 and $60 \mathrm{~min}$ of exposure (Table 2). The

\section{EXPLANATION OF PLATE 2}

All Figs $\times 30$.

Figs 5 and 6. Normal Xenopus laevis embryos; late neurulae and tadpole stages, respectively.

Fig. 7. Abnormal neurulae encountered after sperm pretreatment with EU or TEM. Note irregularities in shape and retardation of growth.

FIG. 8. Various types of abnormal tadpole as seen after sperm exposure to MMS, EU or TEM. 


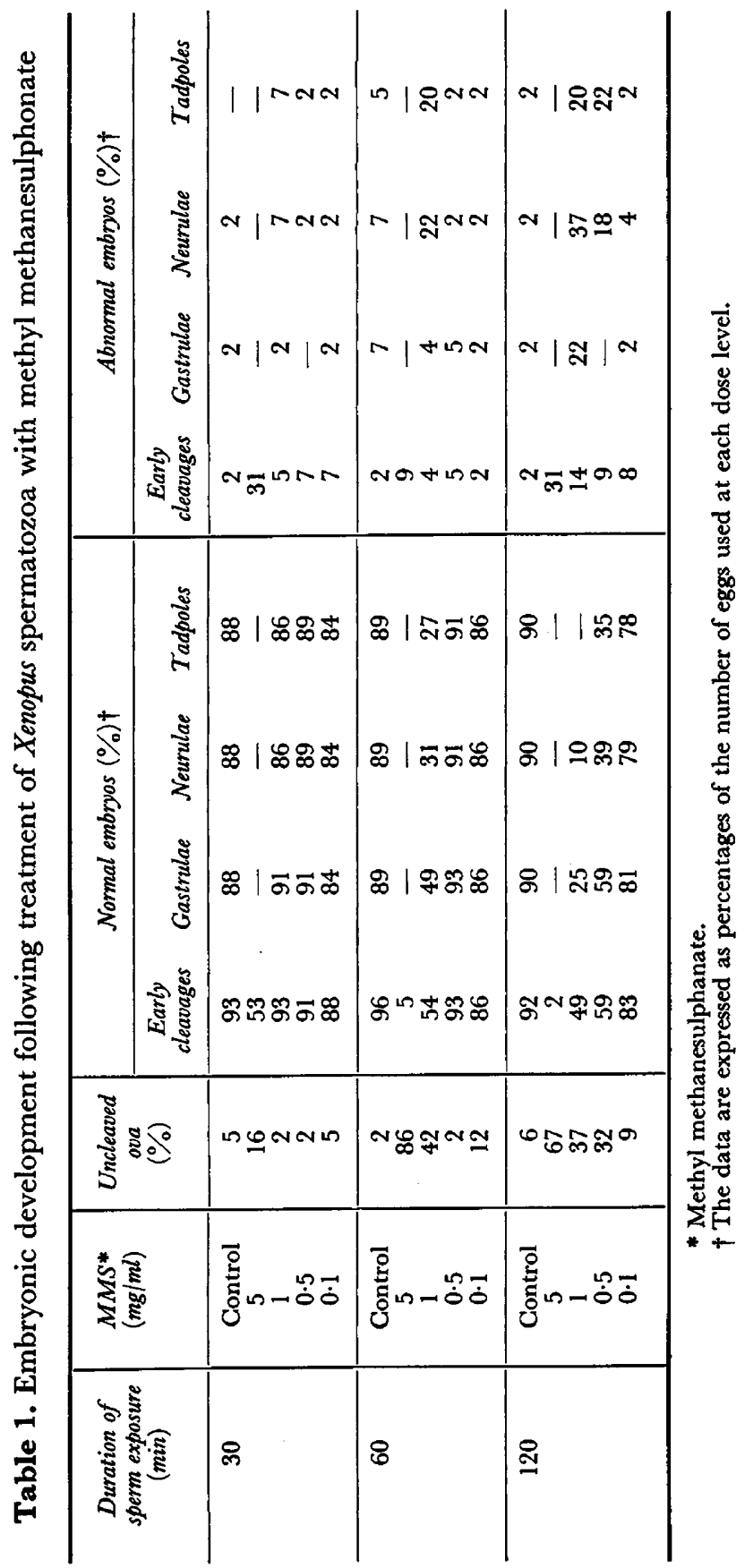




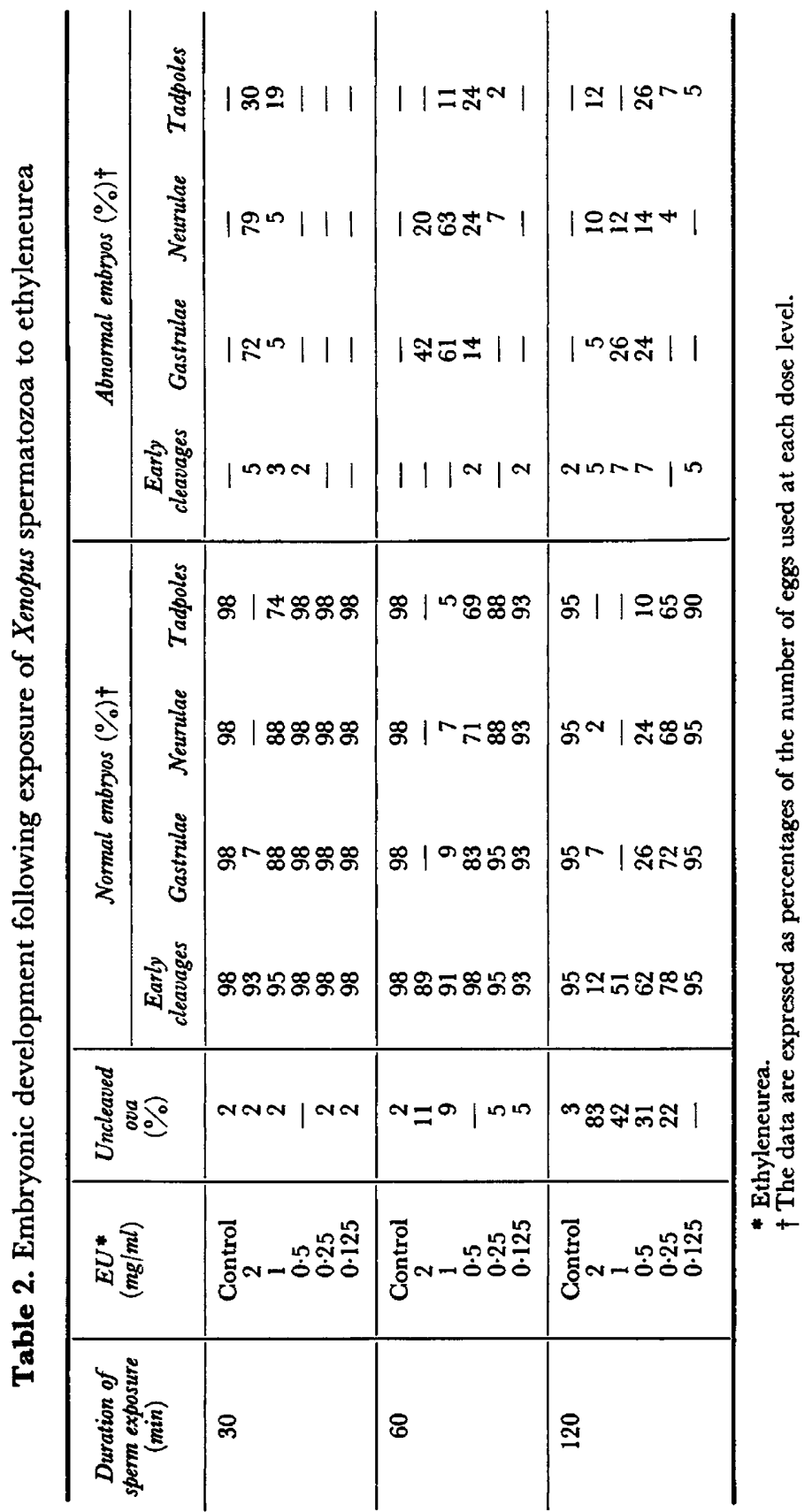




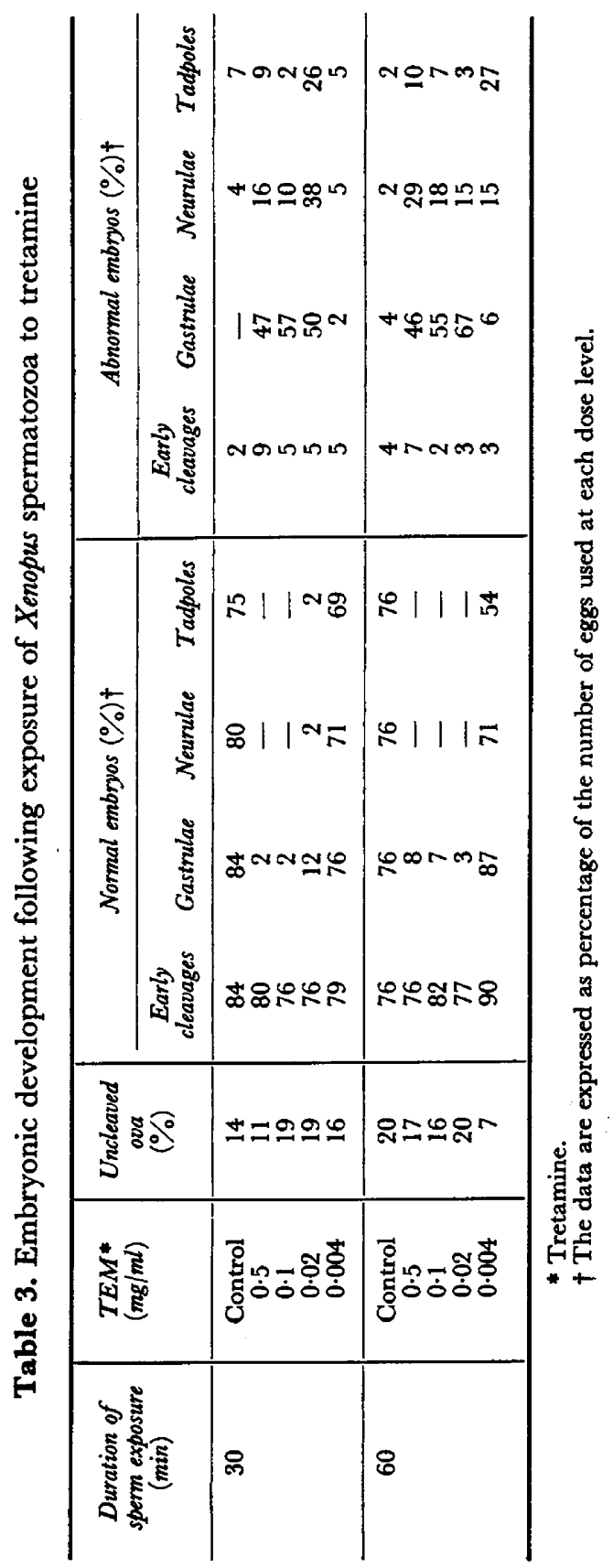




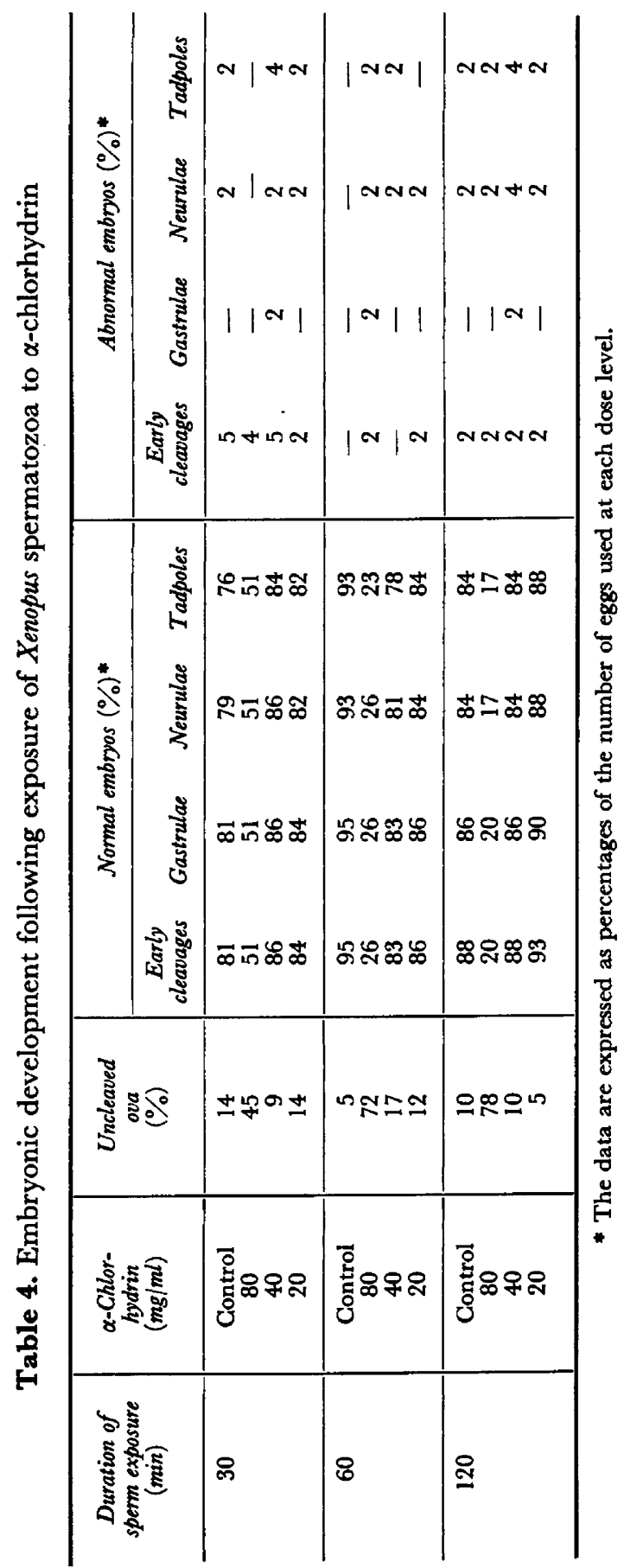


majority of eggs developed abnormally at the highest concentration $(2 \mathrm{mg} / \mathrm{ml})$. At lower dose levels, the toxic effect rapidly disappeared and after exposure for 60 and $120 \mathrm{~min}$, normal development was clearly dose-dependent. Sperm motility after a 2-hr exposure to EU appeared to be reduced at the three higher concentrations.

Tretamine. As expected, TEM showed marked cytotoxic effects on spermatozoa at low concentrations. Although permitting high fertilization and cleavage rates, subsequent development of the eggs was accompanied by a considerable yield of abnormalities at all stages (Table 3 ). Few reached gastrulation at concentrations of 0.5 and $0.1 \mathrm{mg} / \mathrm{ml}$, and none of the subsequent tadpoles was normal. At the lowest concentration $(0.004 \mathrm{mg} / \mathrm{ml})$ the production of tadpoles decreased to $54 \%$ after 60 min of exposure. Sperm motility was not reduced except at the highest concentration.

$\alpha$-Chlorhydrin. Up to the very high level of $40 \mathrm{mg} / \mathrm{ml}$, normal development occurred at all exposure times (Table 4). Few abnormalities were seen even at $80 \mathrm{mg} / \mathrm{ml}$ for $30 \mathrm{~min}$ when $50 \%$ of eggs still developed normally. Longer exposures at this concentration level caused a sharp fall in egg development. Sperm motility was only affected after exposure to the highest concentration for $2 \mathrm{hr}$.

Glycidol. Concentrations of this epoxide between 1 and $0.2 \mathrm{mg} / \mathrm{ml}$ permitted normal development throughout, but spermatozoa treated at 5 and $10 \mathrm{mg} / \mathrm{ml}$ were affected. Thus, after 60 -min treatment about $50 \%$ of eggs failed to cleave in each case. None of the cleaving eggs reached the gastrula stage at $10 \mathrm{mg} / \mathrm{ml}$ while at the $5 \mathrm{mg} / \mathrm{ml}$ level, cleaving eggs continued to the tadpole stage. After 120-min exposure of the spermatozoa, the only difference occurred at the 10 $\mathrm{mg} / \mathrm{ml}$ level when $6 \%$ of the eggs cleaved initially and none developed further. Very few abnormal embryos were seen at any stage.

Trimethylphosphate. From $80 \mathrm{mg}$ TMP/ml downwards, normal development occurred throughout all sperm-exposure times up to $2 \mathrm{hr}$. Furrowing of the animal pole surface without cleavage occurred at higher concentrations of the ester ( 40 and $80 \mathrm{mg} / \mathrm{ml}$ for $60 \mathrm{~min}$ ) or lower concentrations after the maximum exposure (20 and $40 \mathrm{mg} / \mathrm{ml}$ for $120 \mathrm{~min}$ ) but other abnormalities were not induced. There was no notable effect on sperm motility.

Action on ova. The exposure of eggs to the final concentrations of EU, TEM and $\alpha$-chlorhydrin used to treat spermatozoa led to no detectable effect upon their subsequent fertilization by untreated spermatozoa. Cleavage divisions were not delayed and no increase in abnormalities was noted.

\section{DISCUSSION}

Systemic administration to rodents of the compounds used in this study has been shown to affect spermatozoa, either in the lumen of the testis (TEM, EU) or epididymis (TEM, MMS, $\alpha$-chlorhydrin, glycidol and TMP) (see review articles by Jackson, 1964, 1970, for references). Spermatozoa from animals dosed with any of these compounds except $\alpha$-chlorhydrin could fertilize ova but death of the zygote, or early embryo, occurred. Studies have been carried out in vitro on sea-urchin gametes (Fox, Partington \& Jackson, 1963), but the 
use of this test system is limited by the short seasonal reproductive activity of these animals whilst the low temperature of the sea water could greatly reduce the chemical reactivity of certain chemosterilants. The year-round availability of Xenopus gametes obviates this problem, providing a vertebrate system in which the sensitivity of the gametes to chemosterilants should show a closer resemblance to those of experimental rodents.

Factors affecting the viability of Xenopus gametes

Temperature, sperm concentration and ionic strength all influence sperm and egg viability. Initial experiments in the present study, with the gametes maintained in Holtfreter's solution at room temperature, showed a rapid decline in egg fertilizability within $1 \mathrm{hr}$. Sperm fertilizing capacity was retained longer and 50\% tadpole development was recorded even after $4 \mathrm{hr}$.

In a recent study of Xenopus gametes (Wolf \& Hedrick, 1971), both eggs and spermatozoa remained viable in De Boers' solution for longer periods; at working concentrations of this medium ( 0.05 De Boers), however, sperm fertilizability diminished more rapidly than in Holtfreter's solution which was used in the present work.

\section{Effects of antifertility chemicals on Xenopus spermatozoa}

Investigation of the action of MMS in buffer showed that even after a 30-min exposure to a concentration of $5 \mathrm{mg} / \mathrm{ml}$, spermatozoa were still able to initiate $50 \%$ cleavage (Table 1) compared with 0.1 to $1 \mathrm{mg} / \mathrm{ml}$ (unbuffered) in the sea urchin (Echinus esculentus) (Fox et al., 1963). Assuming rapid and uniform distribution of this compound in rat tissues and fluids, its maximal concentration in the testis and epididymis after a sterilizing intraperitoneal dose of $100 \mathrm{mg} / \mathrm{kg}$ (Jackson, Fox \& Craig, 1961) is unlikely to reach $0 \cdot 1 \mathrm{mg} / \mathrm{ml}$. Exposure of Xenopus spermatozoa to $1 \mathrm{mg} / \mathrm{ml}$ for 60 or $120 \mathrm{~min}$ produced $20 \%$ of abnormal tadpoles. This genetically transmitted damage is consistent with the induction of dominant lethal mutations observed during the first 2 weeks after mating MMStreated male mice (Partington \& Bateman, 1964; Moutschen, 1969; Machemer \& Hess, 1971). The mouse results were regarded as a reflection of the high sensitivity of epididymal and testicular spermatozoa and, to a lesser extent, of late spermatids.

High initial cleavage rates were obtained at all concentrations and exposure times with EU and TEM. Effective sterilizing doses in rats $(5 \times 10 \mathrm{mg} \mathrm{EU} / \mathrm{kg}$ and I mg TEM $/ \mathrm{kg}$ ) would not achieve blood concentrations greater than $0.01 \mathrm{mg} \mathrm{EU} / \mathrm{ml}$ and $0.001 \mathrm{mg} \mathrm{TEM} / \mathrm{ml}$. By comparison, $0.5 \mathrm{mg} \mathrm{EU} / \mathrm{ml}$ and $0.02 \mathrm{mg} \mathrm{TEM} / \mathrm{ml}$ produced notable effects on the ability of Xenopus embryos to reach the tadpole stage. Both compounds induced high numbers of exogastrulae and various types of abnormality among tadpoles at the higher concentration levels (Tables 2 and 3). In mice, TEM $(0.4 \mathrm{mg} / \mathrm{kg}$ intraperitoneally) also gave a high yield of dominant lethal mutations (Cattanach \& Edwards, 1958) and a considerable incidence of sterility and semi-sterility in $\mathrm{F}_{1}$ male progeny (Cattanach, 1959).

The epididymal sterilants TMP (Jackson \& Jones, 1968), $\alpha$-chlorhydrin (Ericsson, 1970) and glycidol (Jackson, Campbell \& Jones, 1970) provided an interesting contrast. Very high concentrations of TMP $(80 \mathrm{mg} / \mathrm{ml})$ and 
$\alpha$-chlorhydrin (40 $\mathrm{mg} / \mathrm{ml}$ ) permitted normal tadpole development at all exposure times up to $2 \mathrm{hr}$ (Table 4). The epoxide, glycidol, was more toxic, $1 \mathrm{mg} / \mathrm{ml}$ being the highest concentration compatible with normal development throughout. In male rats, small daily oral doses of $\alpha$-chlorhydrin $(10 \mathrm{mg} / \mathrm{kg})$ effectively sterilized epididymal spermatozoa, so that the concentration in vivo should not exceed $0.01 \mathrm{mg} / \mathrm{ml}$. Similarly, sterilizing doses of TMP to mice $(1 \mathrm{~g} / \mathrm{kg})$ or rats $(100 \mathrm{mg} / \mathrm{kg})$ would correspond to concentrations of about 1 and $0 \cdot 1 \mathrm{mg} / \mathrm{ml}$. These are in striking contrast to the levels tolerated in vitro by toad spermatozoa for relatively long periods of time. Dominant lethal mutations are not induced by $\alpha$-chlorhydrin in rats (Jones, Davies, Edwards \& Jackson, 1969); its action has been shown to make rat spermatozoa incapable of penetrating the egg (Samojlik \& Chang, 1970). Developmental abnormalities were negligible in the toad system with the compound, which may correlate with the absence of a dominant lethal mutation effect in rats. Glycidol by the oral route has an action like $\alpha$-chlorhydrin and may be converted to $\alpha$-chlorhydrin in the rat stomach. The injected compound has a different sterilizing effect (C. M. Jackson A. R. Jones and $\mathbf{H}$. Jackson, unpublished data). The highest concentrations in vivo following a dose to rats $(200 \mathrm{mg} / \mathrm{kg})$ could not reach $0.2 \mathrm{mg} / \mathrm{ml}$. By comparison, the lowest effective concentration of the compound on toad spermatozoa was $5 \cdot 0 \mathrm{mg} / \mathrm{ml}$.

By contrast, oral TMP $(5 \times 100 \mathrm{mg} / \mathrm{kg})$ administered to male rats induced mutagenic effects, manifested by increased numbers of pre- and post-implantation losses during Weeks 2, 3 and 4 after treatment (P. Jones and H. Jackson, unpublished data). This timing corresponds with damage to testicular and epididymal spermatozoa and resembles the action of MMS. No developmental abnormalities were seen following exposure of toad spermatozoa to very high concentrations of TMP. The present results with TMP and $\alpha$-chlorhydrin therefore indicate that their sterilant action in rodents may either involve activation of their molecules or some indirect effect on spermatozoa. With the exception of TEM, the effective concentrations and times of exposure were greatly in excess of those likely to occur after antifertility doses to experimental rodents.

In view of the alkylating nature of these compounds and the fact that their reactivity in vitro will probably be temperature-dependent, the environmental difference must also be taken into account when comparing dose levels used in different species. In mammals, the sperm environment is around $35^{\circ} \mathrm{C}$ whereas in Xenopus, spermatozoa are maintained at 20 to $22^{\circ} \mathrm{C}$. This temperature difference could account for the higher concentration of compounds required in the latter system but not for the ineffectiveness of $\alpha$-chlorhydrin and TMP. Although this in-vitro system enables developmental abnormalities to be produced by the action of some chemical mutagens, others, like TMP, are able to produce genetic damage through their effect on mammalian spermatozoa but are ineffective on Xenopus spermatozoa.

\section{AGKNOWLEDGMENTS}

This work was supported by grants from the Ford Foundation and the Medical Research Council. 


\section{REFERENCES}

Cattanach, B. M. (1959) The sensitivity of the mouse testis to the mutagenic action of triethylenemelamine. Z. VererbLehre, 90, 1.

Cattanach, B. M. \& Edwards, R. G. (1958) The effects of triethylene-melamine on the fertility of male mice. Proc. R. Soc. Edinb. B, 67, 54.

ERICsson, R. J. (1970) Male antifertility compounds: U-5897 as a rat chemosterilant. F. Reprod. Fert. 22, 213.

Fox, B. W., Partington, M. \& Jackson, H. (1963) Action of alkylating agents on sea urchin gametes. Expl Cell Res. 29, 137.

Jackson, H. (1964) The effects of alkylating agents on fertility. Br. med. Bull. 20, 107.

Jackson, H. (1970) Antispermatogenic agents. Br. med. Bull. 26, 79.

Jackson, H., Campbell, I. S. C. \& Jones, A. R. (1970) Is glycidol an active intermediate in the antifertility action of $\alpha$-chlorhydrin in male rats? Nature, Lond. 226, 86.

Jackson, H., Fox, B. W. \& Craig, A. W. (1961) Antifertility substances and their assessment in the male rodent. 7. Reprod. Fert. 2, 447.

JACKson, H. \& Jones, A. R. (1968) Antifertility action and metabolism of trimethylphosphate in rodents. Nature, Lond. 220, 591.

Jones, A. R., Davies, P., Edwards, K. \& Jackson, H. (1969) Antifertility effects and metabolism of $\alpha$ - and epi-chlorhydrins in the rat. Nature, Lond. 224, 83.

Leadley Brown, A. (1970) The African Clawed Toad. Butterworths, London.

Machemer, L. \& Hess, R. (1971) Comparative dominant lethal studies with phenylbutazone, thioTEPA and MMS in the mouse. Experientia, 27, 1050.

Moutschen, J. (1969) Mutagenesis with methyl methanesulphonate in mouse. Mutat. Res. 8, 581.

New, D. A. T. (1966) The Culture of Vertebrate Embryos, p. 125. Logos Press, London.

Nieuwroop, P. D. \& Faber, J. (1956) Normal Table of Xenopus laevis (Daud.). North-Holland Publishing Co., Amsterdam.

Partington, M. \& Bateman, A. J. (1964) Dominant lethal mutations induced in male mice by methyl methanesulphonate. Heredity, Lond. 19, 191.

Ruddock, P. A. \& Ruffle, W. G. (1972) The care and maintenance of a breeding Xenopus colony. 7. Inst. anim. Techns, 23, 83.

Rugh, R. (1962) Experimental Embryology, p. 76. Burgess Press, Minneapolis.

Samojlik, E. \& Chang, M. C. (1970) Antifertility activity of 3-chloro-1,2-propanediol (U-5897) on male rats. Biol. Repiod. 2, 299.

Wolf, D. P. \& Hedrick, J. L. (1971) A molecular approach to fertilization. II. Viability and artificial fertilization of Xenopus laevis gametes. Devl Biol. 25, 348. 